\title{
Molecular Tectonics: 1D Tubular Type and 3D Diamond Like Mercury(II) Coordination Polymers Based on Pyridyl Appended p-tert-Butyltetrathiacalix[4]arene
}

\author{
A. S. Ovsyannikov, ${ }^{\mathrm{a}, \mathrm{c}}{ }^{1}$ S. Ferlay, ${ }^{\mathrm{b} @ 2}$ S. E. Solovieva, ${ }^{\mathrm{c}}{ }^{1}$. S. Antipin, ${ }^{\mathrm{c}}$ A. I. Konovalov, ${ }^{\mathrm{a}}$ \\ N. Kyritsakas, ${ }^{\mathrm{b}}$ and M. W. Hosseini ${ }^{\mathrm{b} @ 3}$
}

Dedicated to Academician of Russian Academy of Sciences Oleg G. Sinyashin on the occasion of his $60^{\text {th }}$ Anniversary \begin{abstract}
Kazan, Russian Federation
${ }^{\circledR 1}$ E-mail: osaalex2007@rambler.ru

@2E-mail:ferlay@unistra.fr

${ }^{\circledR 3}$ E-mail: hosseini@unistra.fr
\end{abstract}

${ }^{a}$ Kazan Federal University, 420008 Kazan, Russian Federation

${ }^{\mathrm{b}}$ Molecular Tectonics Laboratory, University of Strasbourg, UMR UDS-CNRS 7140, Institut le Bel, F-67000 Strasbourg, France 'A.E. Arbuzov Institute of Organic and Physical Chemistry, Kazan Scientific Center, Russian Academy of Science, 420088

1D Tubular-type and 3D diamond-like coordination polymers are formed upon combining pyridyl appended p-tertbutyltetrathiacalix[4]arene in 1,3-alternate conformation tectons 4 and 5 with mercury(II) chloride.

Keywords: Molecular tectonics, coordination polymer, tetrathiacalix[4]arene, mercury.

\section{Молекулярная тектоника: 1D тубулярная структура и 3D алмазоподобная структура координационных полимеров на основе взаимодействия тетразамещённых пиридильных

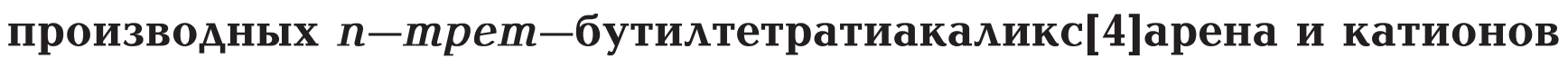 ртути(II)}
А. С. Овсянников, ${ }_{1}^{\text {a,c@1 }}$
С. Ферлэй,
С. Е. Соловьёва, ${ }^{\mathrm{C}}$ И. С. Антипин ${ }_{1}^{\mathrm{C}}$
А. И. Коновалов, ${ }^{a}$ Н. Киритсакас, ${ }^{b}$ М.
В. Хоссейни ${ }^{\mathrm{Q}}$

Посвящается акаgемику РАН Олегу ГерольgовичуСиняшину по случаю его 60-летнего юбилея

${ }^{a}$ Казанский федеральный университет, 420008 Казань, Россия

bЛаборатория молекулярной тектоники, Университет Страсбурга, F-67000 Страсбург, Франџия

' Институт органической и физической химии им. А.Е. Арбузова КазНЦ РАН, 420088 Казань, Россия

${ }^{\circledR 1}$ E-mail: osaalex2007@rambler.ru

${ }^{\circledR 2}$ E-mail:ferlay@unistra.fr

${ }^{\circledR 3}$ E-mail: hosseini@unistra.fr

Взаимодействие хлорида ртути(II) с тетразамещёнными пиридильными производными п-трет-бутилтетратиакаликс[4]арена 4 и 5 в конформации 1,3-альтернат привело к получению двух новых координащионных полимеров: $1 D$ тубулярного типа и $3 D$ алмазоподобного типа.

Ключевые слова: Молекулярная тектоника, координационный полимер, тетратиакаликс[4]арен, ртуть. 


\section{Introduction}

Molecular tectonics ${ }^{[1]}$ is a strategy dealing with the design and analysis of extended periodic architectures like molecular networks in the crystalline phase. This approach relies on concepts such as molecular recognition developed in supramolecular chemistry. ${ }^{[2]}$ Thus, molecular networks are designed and generated through translations of recognition events taking place between molecular building blocks or tectons. ${ }^{[3]}$ This strategy is a powerful approach for the design of crystalline periodic molecular architectures that may display functional features if the tectons possess of specific properties or if their arrangement in space leads to emergence of properties, such as porosity for example.

Coordination polymers, ${ }^{[4]}$ a subclass of molecular networks, may be designed using concepts developed in molecular tectonics. Coordination networks are extended periodic assemblies resulting from the bridging by metal cations (or metal complexes as metallatectons) of coordinating organic tectons through establishment of coordination bonds. The rational design of coordination networks, still not completely mastered and operational, continues to attract considerable interest and requires

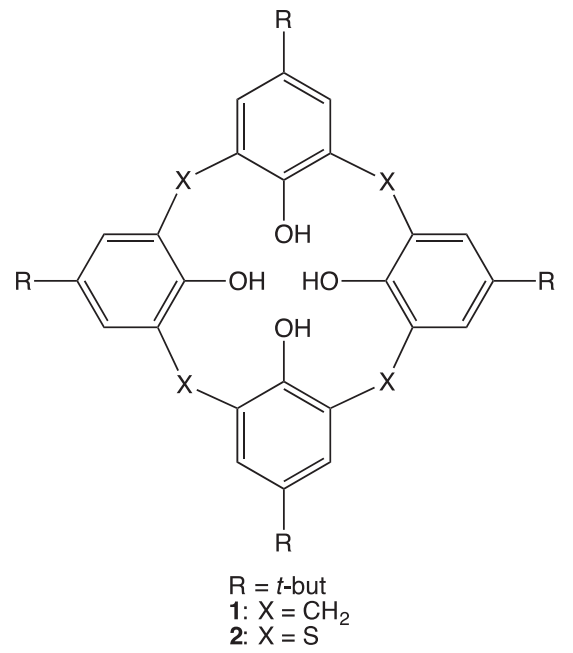

Figure 1. Calix[4]arene (CA) 1 and thiacalix[4]arene (TCA) 2. experimental investigations to unravel subtleties governing self-assembly processes.

Calix[4] $\operatorname{arene}^{[5]}$ (1, Figure 1), a macrocyclic organic entity, is composed of four phenol moieties connected by the $\mathrm{CH}_{2}$-groups. For steric reasons, this platform is not planar but adopts four limit conformations (cone, partial cone, 1,2-alternate and 1,3-alternate). Among these, the 1,3-alternate conformer is particularly well suited for the design of coordinating tectons since such conformation allows to position up to four coordinating sites (two above and two below the main plane of the macrocyclic backbone). This design principle has been widely exploited for the generation of molecular networks variety, in particular, 1D3D coordination networks based on combinations of calix[4] arene derivatives in cone or 1,3-alternate conformation bearing coordinating groups such as cyano, ${ }^{[6]}$ carboxyl, ${ }^{[7-9]}$ thiacrown, ${ }^{[10-14]}$ have been reported.

Thiacalix[4] arene (TCA) for which the bridging methylene groups are replaced by $\mathrm{S}$ atoms $(2$, Figure 1$){ }^{[15]}$ and tetramercaptothiacalixarenes (TMTCA) for which both the bridging methylene groups and the $\mathrm{O}$ atoms are replaced by $\mathrm{S}$ atoms ${ }^{[16]}$ are structural analogues of calix[4]arene. However, for both TCA and TMTCA, the presence of bridging $\mathrm{S}$ atoms not only leads to an enhancement of the size of the macrocycle cavity but also provides additional coordinating sites. Tetrasubstituted thiacalix[4]arene derivatives bearing cyano, ${ }^{[17-19]}$ carboxyl, ${ }^{[20-22]}$ pyridyl, ${ }^{[23-28]}$ coordinating groups were combined with metal cations for the formation of coordination networks displaying a variety of dimensionalities (1D-3D). In contrast to CA, for these sulfur containing tectons, only the 1,3-alternate conformation has been used. The tetrasubstitution of the 1,3-alternate conformer leads to a S4 symmetry in which the four coordinating sites occupy the apices of a tetrahedron. We have previously shown that TCA pyridyl based tectons 3, 4, 5 (Figure 2), differing by the position of the $\mathrm{N}$ atom on the pyridyl moiety, lead to the formation of silver coordination networks. Furthermore, it has been demonstrated that the dimensionality of the resulting network may be controlled either by the localization of the $\mathrm{N}$ atoms or by the nature of the counter ions. ${ }^{[23,27]}$

Here, we report on the preparation of two new coordination networks obtained by combining pyridyl TCA

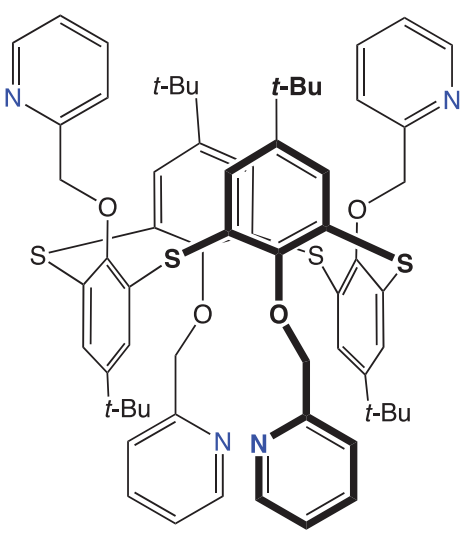

3

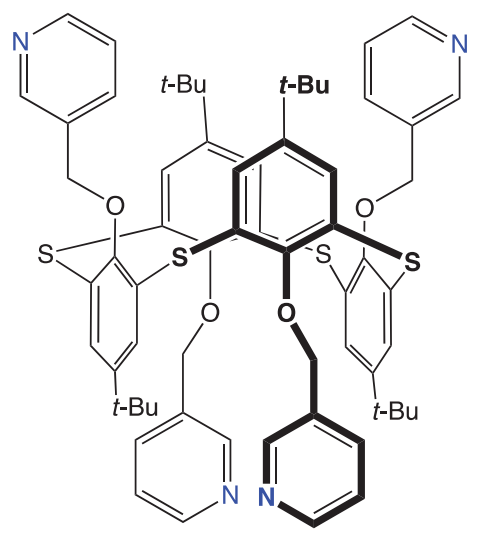

4

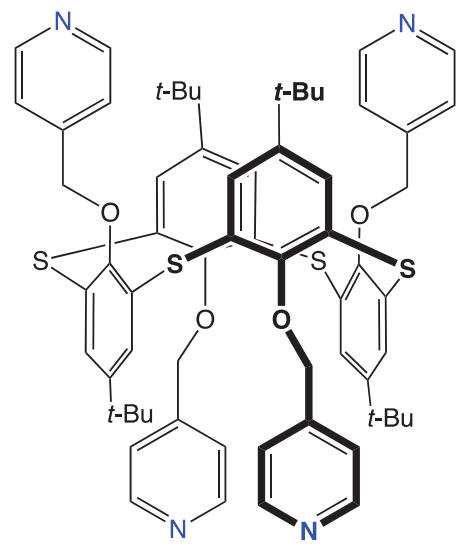

5 
derivatives in 1,3-alternate conformation 4 ( $\mathrm{N}$ atom of the pyridyl in meta position) and $\mathbf{5}(\mathrm{N}$ atom of the pyridyl in para position) (Figure 2) with $\mathrm{HgCl}_{2}$, acting as $\mathrm{V}$-shape twoconnecting metallatecton.

\section{Experimental}

Compounds 3, 4, 5 have been synthesized as previously reported. ${ }^{[23]}$

Elemental analyses were performed by the Service de Microanalyses de la Fédération de Recherche Chimie, Université de Strasbourg, Strasbourg, France.

Data for X-ray analysis were collected at 173(2) K on a Bruker APEX8 CCD Diffractometer equipped with an Oxford Cryosystem liquid $\mathrm{N}_{2}$ device, using graphite-monochromated Mo-K $\alpha(\lambda=$ $0.71073 \AA$ ) radiation. For all structures, diffraction data were corrected for absorption. Structures were solved using SHELXS-97 and refined by full matrix least-squares on $F^{2}$ using SHELXL-97. The hydrogen atoms were introduced at calculated positions and not refined (riding model). ${ }^{[29]}$ They can be obtained free of charge from the Cambridge Crystallographic Data Centre via www.ccdc. cam.ac.uk/datarequest/cif. CCDC: 1433709-1433710.

\section{Crystallisation Conditions}

4- $\mathrm{HgCl}_{2}:$ Formula $\left\{\mathrm{Hg}_{3} \mathrm{Cl}_{6}\left(\mathrm{C}_{64} \mathrm{H}_{68} \mathrm{~N}_{4} \mathrm{O}_{4} \mathrm{~S}_{4}\right) 2\left(\mathrm{CHCl}_{3}\right)\right\}$. In a crystallization tube ( $4 \mathrm{~mm}$ diameter, $15 \mathrm{~cm}$ height), a solution of the compound $4(5 \mathrm{mg}, 0.0046 \mathrm{mmol})$ in $\mathrm{CHCl}_{3}(1 \mathrm{ml})$ was layered with a $1 / 1 \mathrm{CHCl}_{3}$ /iso-PrOH mixture $(1 \mathrm{ml})$. A solution of $\mathrm{HgCl}_{2}$ $(2.5 \mathrm{mg}, 0.0092 \mathrm{mmol})$ in $\mathrm{MeOH}(1 \mathrm{ml})$ was carefully added. Slow diffusion at room temperature produced after one month colourless crystals suitable for X-ray diffraction studies. Found, \%: C, 48.86; $\mathrm{H}, 4.35 ; \mathrm{N}, 3.40 . \mathrm{Hg}_{3} \mathrm{Cl}_{6}\left(\mathrm{C}_{64} \mathrm{H}_{68} \mathrm{~N}_{4} \mathrm{O}_{4} \mathrm{~S}_{4}\right)_{2}\left(\mathrm{CHCl}_{3}\right)_{2}$. Calculated, \%: C, $48.43 ; \mathrm{H}, 4.31 ; \mathrm{N}, 3.48$.

5- $\mathrm{HgCl}_{2}$ : Formula $\left\{\mathrm{Hg}_{2} \mathrm{Cl}_{4}\left(\mathrm{C}_{64} \mathrm{H}_{68} \mathrm{~N}_{4} \mathrm{O}_{4} \mathrm{~S}_{4}\right) \cdot 4 \mathrm{CHCl}_{3}\right\}$. In a crystallization tube (4 $\mathrm{mm}$ diameter, $15 \mathrm{~cm}$ height), a solution of compound $5(5 \mathrm{mg}, 0.0046 \mathrm{mmol})$ in $\mathrm{CHCl}_{3}(1 \mathrm{ml})$ was layered with a $1 / 1 \mathrm{CHCl}_{3} /$ iso-PrOH mixture $(1 \mathrm{ml})$. A solution of $\mathrm{HgCl}_{2}(2.5 \mathrm{mg}$, $0.0092 \mathrm{mmol})$ in $\mathrm{MeOH}(1 \mathrm{ml})$ was carefully added. Slow diffusion at room temperature produced after $c a$ one month colourless crystals suitable for X-ray diffraction studies. Found, \%: C, 38.90; $\mathrm{H}, 3.55 ; \mathrm{N}, 2.51 . \mathrm{Hg}_{2} \mathrm{Cl}_{4}\left(\mathrm{C}_{64} \mathrm{H}_{68} \mathrm{~N}_{4} \mathrm{O}_{4} \mathrm{~S}_{4}\right)\left(\mathrm{CHCl}_{3}\right)_{4}$. Calculated, \%: C, $38.78 ; \mathrm{H}, 3.45 ; \mathrm{N}, 2.66$.

\section{Results and Discussion}

With the aim of generating coordination networks, compounds 3, 4, and $\mathbf{5}$ (Figure 2) were combined under selfassembly conditions with $\mathrm{HgCl}_{2}$. Although for compound $\mathbf{3}$ no crystalline material was obtained, for tectons $\mathbf{4}$ and $\mathbf{5}$, colorless single crystals were obtained upon slow diffusion, through a $\mathrm{CHCl}_{3}$ /iso-PrOH layer, of $\mathrm{MeOH}$ solution of $\mathrm{HgCl}_{2}$ into a $\mathrm{CHCl}_{3}$ solution of $\mathbf{4}$ or $\mathbf{5}$ (see Experimental). X-Ray diffraction on single crystals revealed that whereas the use of the tecton 4 leads to the formation of the 3D mercury coordination network, for tectons $\mathbf{5}$ the 1D coordination networks is generated in the crystalline phase. In both cases, $\mathrm{Hg}^{2+}$ cation, adopting a distorted tetrahedral geometry with two of the four apices occupied by two $\mathrm{Cl}^{-}$anions, behaves as a V-type two-connecting node.

As mentioned above, the combination of 4 with $\mathrm{HgCl}_{2}$ leads to a neutral $3 \mathrm{D}$ coordination polymer $4-\mathrm{HgCl}_{2}\left(\left\{\mathrm{Hg}_{3} \mathrm{Cl}_{6}\right.\right.$ $\left.\left(\mathrm{C}_{64} \mathrm{H}_{68} \mathrm{~N}_{4} \mathrm{O}_{4} \mathrm{~S}_{4}\right)_{2} 2 \mathrm{CHCl}_{3}\right\}$ ) with a $4 / \mathrm{Hg}$ ratio of $2 / 3$ (Figure 3a, Table 2). $4-\mathrm{HgCl}_{2}$ crystallizes in the $\mathrm{F} d d 2$ orthorhombic space group. Within the crystal, two crystallographically independent $\mathrm{Hg}^{2+}$ cations ( $\mathrm{Hg} 1$ and $\mathrm{Hg} 2$ ) with the same distorted tetrahedron geometry and $\mathrm{N}_{2} \mathrm{Cl}_{2}$ environment are present. For bond distances and angles, see Table 1. Both types of $\mathrm{Hg}^{2+}$ cations bridge two adjacent tectons $\mathbf{4}$ via the pendent pyridyl moieties. S atoms of $\mathbf{4}$ are not involved in the coordination with $\mathrm{Hg}^{2+}$ cations. Among the four coordinating pyridyl units, only three take part in the formation of the extended 3D architecture. Each neutral $\mathrm{HgCl}_{2}$ metallatecton is surrounded by two organic tectons 4 and each tecton 4 is surrounded by three $\mathrm{HgCl}_{2}$ units. The $3 \mathrm{D}$ diamond-like structure $4-\mathrm{HgCl}_{2}$ may be described as: i) the generation of a "superpolyhedrons" resulting from the bridging of two adjacent tectons 4 , for which the $\mathrm{N}$ atoms of the pyridyl units occupy the apices of a distorted tetrahedron, by a $\mathrm{Hg} 2$ type cation through $\mathrm{N}-\mathrm{Hg}$ coordination bonds between the metal center and $\mathrm{N}$ atoms of the pyridyl moieties (Figure $3 \mathrm{~b}$ ); ii) the interconnection of "superpolyhedrons" through $\mathrm{N}-\mathrm{Hg}$ bonds between the two remaining two pyridyl moieties of 4 with $\mathrm{Hg} 1$ type cations (Figure 4). Although crystal of 4- $\mathrm{HgCl}_{2}$ contain two $\mathrm{CHCl}_{3}$ molecules occupying the pores,

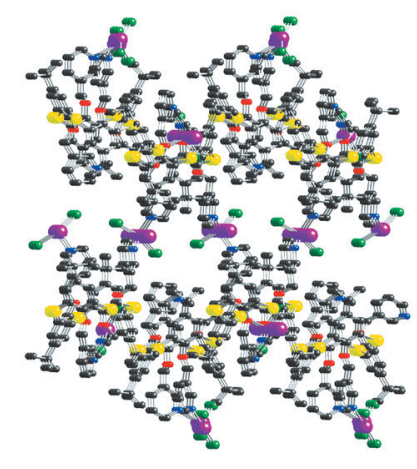

a

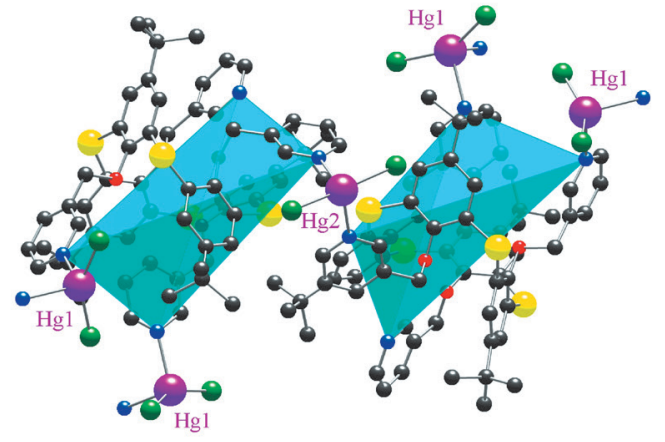

b

Figure 3. 3D coordination network $4-\mathrm{HgCl}_{2}$ generated upon combining the organic tecton 4 and $\mathrm{HgCl}_{2}$ as a two connecting metallatecton: a) a portion of crystal structure; b) structure of a "superpolyhedron" resulting from the bridging of two tectons $\mathbf{4}$ by a $\mathrm{Hg} 1$ type cation and the propensity of the subunit to bind $\mathrm{Hg} 1$ type cations leading to the formation of the 3D architecture. Solvents molecules and $\mathrm{H}$ atoms are omitted for clarity. 


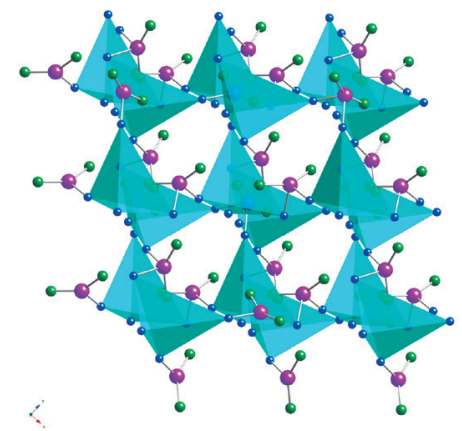

Figure 4. Polyhedral representation of the crystal structure of the $3 \mathrm{D}$ diamond-like coordination polymer $4-\mathrm{HgCl}_{2}$ in the $\mathrm{xOz}$ plane.

Table 1. Main characteristics (bond distances and angles) for 4- $\mathrm{HgCl}_{2}$ and $\mathbf{5}-\mathrm{HgCl}_{2}$.

\begin{tabular}{|c|c|c|}
\hline & $4-\mathrm{HgCl}_{2}$ & $5-\mathrm{HgCl}_{2}$ \\
\hline $\mathrm{d}\left(\mathrm{Hg} 1-\mathrm{N}_{\mathrm{Py}}\right), \AA$ & $\begin{array}{c}2.395(10) \\
2.43(5)\end{array}$ & $\begin{array}{l}2.398(4) \\
2.423(4)\end{array}$ \\
\hline $\mathrm{d}\left(\mathrm{Hg} 2-\mathrm{N}_{\mathrm{Py}}\right), \AA$ & $2.414(7)$ & $\begin{array}{l}2.407(4) \\
2.414(4)\end{array}$ \\
\hline $\mathrm{d}\left(\mathrm{Hg} 1-\mathrm{Cl}_{\mathrm{x}}\right), \AA$ & $\begin{array}{l}2.319(6) \\
2.380(5)\end{array}$ & $\begin{array}{l}2.3565(15) \\
2.3892(14)\end{array}$ \\
\hline $\mathrm{d}\left(\mathrm{Hg} 2-\mathrm{Cl}_{\mathrm{x}}\right), \AA$ & $2.364(2)$ & $\begin{array}{l}2.3535(15) \\
2.3926(15)\end{array}$ \\
\hline$\angle\left(\mathrm{N}_{\mathrm{Py}}-\mathrm{Hg} 1-\mathrm{N}_{\mathrm{Py}}\right),{ }^{\circ}$ & $93.8(15)$ & $107.79(14)$ \\
\hline$\angle\left(\mathrm{N}_{\mathrm{Py}}-\mathrm{Hg} 2-\mathrm{N}_{\mathrm{Py}}\right){ }^{\circ}$ & $89.0(3)$ & $113.66(14)$ \\
\hline$\angle\left(\mathrm{Cl}_{\mathrm{x}}-\mathrm{Hg} 1-\mathrm{N}_{\mathrm{Py}}\right),{ }^{\circ}$ & $\begin{array}{l}98.4(9) \\
95.5(3)\end{array}$ & $\begin{array}{c}104.34(11) \\
94.84(11) \\
100.43(11) \\
93.30(11)\end{array}$ \\
\hline$\angle\left(\mathrm{Cl}_{\mathrm{x}}-\mathrm{Hg} 2-\mathrm{N}_{\mathrm{Py}}\right),{ }^{\circ}$ & $\begin{array}{l}99.74(19) \\
94.73(19)\end{array}$ & $\begin{array}{c}100.90(12) \\
91.48(12) \\
102.93(11) \\
91.28(11)\end{array}$ \\
\hline$\angle\left(\mathrm{Cl}_{\mathrm{x}}-\mathrm{Hg} 1-\mathrm{Cl}_{\mathrm{y}}\right),{ }^{\circ}$ & 149.6(2) & $151.54(6)$ \\
\hline$\angle\left(\mathrm{Cl}_{\mathrm{x}}-\mathrm{Hg} 2-\mathrm{Cl}_{\mathrm{y}}\right),{ }^{\circ}$ & $159.67(11)$ & $155.29(5)$ \\
\hline
\end{tabular}

no specific interactions between them and the framework could be spotted.

Unfortunately, probably owing to the loss of $\mathrm{CHCl}_{3}$ solvents molecules, crystals of $4-\mathrm{HgCl}_{2}$ were found to be unstable outside of the crystallization solution and thus all attempts to record the XRPD diagrams failed.

In marked contrast with the 3D architecture discussed above, tecton 5 (Figure 2), also bearing four pyridyl groups but differing from the tecton 4 by the position of the $\mathrm{N}$ atom on pyridyl units (meta in the case of $\mathbf{4}$ and para for tecton $\mathbf{5}$ ), leads to the formation of a neutral 1D tubular type coordination polymer in the presence of $\mathrm{HgCl}_{2}$ (Figure 5, Table 3). 5- $\mathrm{HgCl}_{2}\left(\left\{\mathrm{Hg}_{2} \mathrm{Cl}_{4}\left(\mathrm{C}_{64} \mathrm{H}_{68} \mathrm{~N}_{4} \mathrm{O}_{4} \mathrm{~S}_{4}\right) \cdot 4 \mathrm{CHCl}_{3}\right\}\right)$ crystallizes in the $\mathrm{P} 2 / n$ monoclinic space group. The crystal is composed of $\mathbf{5}, \mathrm{HgCl}_{2}$ and $\mathrm{CHCl}_{3}$ molecules, with a $1 / 2 \mathbf{5} / \mathrm{HgCl}_{2}$ ratio. Each $\mathrm{HgCl}_{2}$ is surrounded by two organic tectons $\mathbf{5}$ and each tecton $\mathbf{5}$ is surrounded by four $\mathrm{HgCl}_{2}$ units. In marked contrast with the above discussed 3D network 4- $\mathrm{HgCl}_{2}$, all four pyridyl units belonging to tecton 5 participate in binding of neutral $\mathrm{V}$-shaped $\mathrm{HgCl}_{2}$ species via four $\mathrm{N}$ atoms of the divergently disposed pyridyl moieties.

As in the case of $4-\mathrm{HgCl}_{2}$, the two crystallographically independent $\mathrm{Hg}^{2+}$ cations are adopting a distorted tetrahedral coordination geometry and are surrounded by two $\mathrm{N}$ atoms belonging to pyridyl moieties of the same tecton $\mathbf{5}$ and two chlorine anions (for bond distances and angles see Table 1). As in the previous case, the sulfur atoms of $\mathbf{5}$ do not interact with $\mathrm{Hg}^{2+}$ cations. The tubular type architecture is analogous to previously reported studies on other macrocycle based tectons such as metacyclophanes, ${ }^{[30]}$ or calixarenes $^{[31]}$ bearing monodentate binding sites. The same type of 1D network has been also obtained using pyridyl appended tetramercaptothiacalix[4]arene. ${ }^{[26]}$

In the crystal, the $1 \mathrm{D}$ networks are packed in a parallel fashion along $(0,1,0)$ crystallographic plane and form layers (Figure 6a). The latter are stacked in an antiparallel fashion along the $b$ axis (Figure 6b), leading thus to formation of square shaped channels along the $a$ axis (Figure 6c). The latter are filled with $\mathrm{CHCl}_{3}$ molecules without any specific interactions with the coordination network.

Again, as in the case of $4-\mathrm{HgCl}_{2}$, because of the instability of crystals in the air, no XRPD diagram of compound 5- $\mathrm{HgCl}_{2}$ could not be recorded at room temperature.

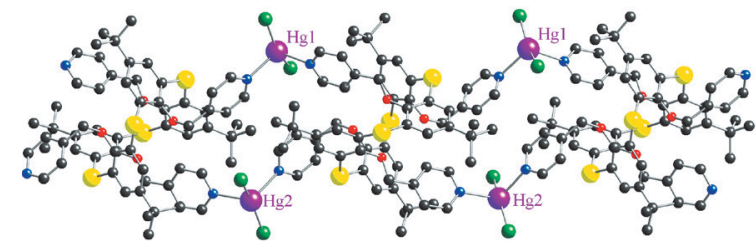

a

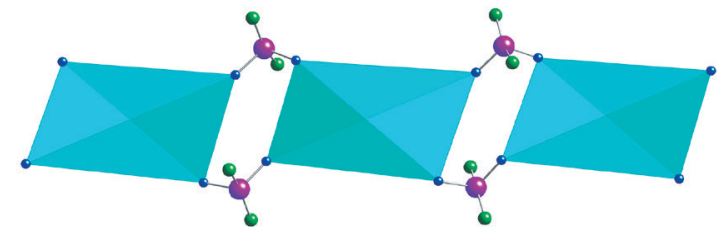

b

Figure 5. 1D coordination polymer $5-\mathrm{HgCl}_{2}$ obtained upon combining the organic tecton $\mathbf{5}$ and $\mathrm{HgCl}_{2}$ : a) a portion of the crystal structure showing the presence of two crystallographically nonequivalent $\mathrm{Hg}$ atoms $(\mathrm{Hg} 1$ and $\mathrm{Hg} 2)$ and their bridging role in the formation of the extended coordination network, b) a polyhedral representation of the tubular type architecture showing the bridging of consecutive tectons 5 by $\mathrm{HgCl}_{2}$ metallatecton in the yOz plane. Solvents molecules and $\mathrm{H}$ atoms are omitted for clarity. 


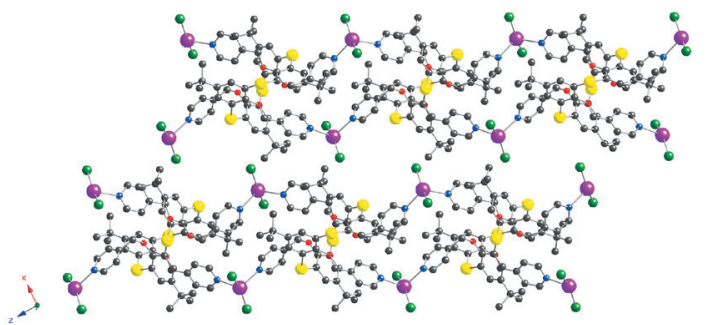

a

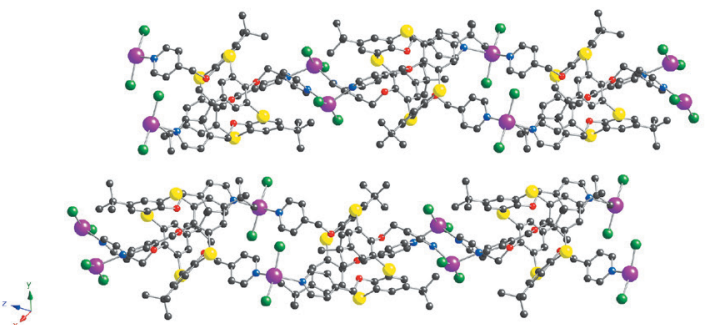

b

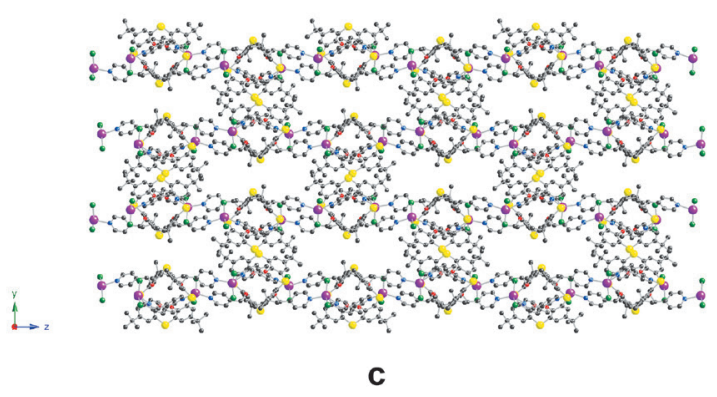

Figure 6. Crystal packing of 5- $\mathrm{HgCl}_{2}$ : a) parallel packing of 1D tubular networks, b) antiparallel arrangement of layers resulting from the packing of 1D networks along $b$ axis, c) formation of square channels along $a$ axis. Solvents molecules and $\mathrm{H}$ atoms are omitted for clarity.

Table 2. Crystal data for $\left\{\mathrm{Hg}_{3} \mathrm{Cl}_{6}\left(\mathrm{C}_{64} \mathrm{H}_{68} \mathrm{~N}_{4} \mathrm{O}_{4} \mathrm{~S}_{4}\right)_{2} \cdot 2\left(\mathrm{CHCl}_{3}\right)\right\} \cdot 4-\mathrm{HgCl}_{2}$.

\begin{tabular}{ll}
\hline Empirical formula & $\left\{\mathrm{Hg}_{3} \mathrm{Cl}_{6}\left(\mathrm{C}_{64} \mathrm{H}_{68} \mathrm{~N}_{4} \mathrm{O}_{4} \mathrm{~S}_{4}\right)_{2} 2\left(\mathrm{CHCl}_{3}\right)\right\}$ \\
Formula weight & 3224.13 \\
Temperature & $173(2) \mathrm{K}$ \\
Wavelength & $0.71073 \AA$ \\
Crystal system & Orthorhombic \\
Space group & $\mathrm{Fdd} 2$ \\
Unit cell dimensions & $\mathrm{a}=22.2654(6) \AA \alpha=90^{\circ}$. \\
& $\mathrm{b}=69.809(2) \AA \beta=90^{\circ}$. \\
& $\mathrm{c}=19.4799(6) \AA \gamma=90^{\circ}$. \\
Volume & $30278.1(16) \AA^{3}$ \\
Z & 8 \\
Density (calculated) & $1.415 \mathrm{Mg} / \mathrm{m}^{3}$ \\
Absorption coefficient & $3.408 \mathrm{~mm} \mathrm{~m}^{-1}$ \\
F(000) & 12880 \\
Crystal size & $0.09 \times 0.07 \times 0.06 \mathrm{~mm}{ }^{3}$ \\
Theta range for data collection & 1.42 to $30.09^{\circ}$. \\
Index ranges & $-21<=\mathrm{h}<=29,-98<=\mathrm{k}<=97$, \\
& $-27<=1<=27$ \\
Reflections collected & 136672 \\
Independent reflections & $21188[\mathrm{R}($ int $)=0.0683]$ \\
Completeness to theta $=30.09^{\circ}$ & $97.5 \%$ \\
Absorption correction & $\mathrm{Semi}-\mathrm{empirical}$ from equivalents \\
Max. and min. transmission & 0.8216 and 0.7490 \\
Refinement method & $\mathrm{Full-matrix} \mathrm{least-squares} \mathrm{on} \mathrm{F}^{2}$ \\
Data / restraints / parameters & $21188 / 31 / 770$ \\
Goodness-of-fit on F $\mathrm{F}^{2}$ & 1.041 \\
Final R indices [I 2 sigma(I) $]$ & $\mathrm{R} 1=0.0770, \mathrm{wR} 2=0.2034$ \\
R indices (all data) & $\mathrm{R} 1=0.1265, \mathrm{wR} 2=0.2286$ \\
Absolute structure parameter & $0.042(7)$ \\
Largest diff. peak and hole & 1.251 and $-0.946 \mathrm{e} \cdot \AA^{-3}$ \\
\hline & \\
&
\end{tabular}

\section{Conclusion}

Combinations of tetrapyridyl appended thiacalix[4]arene in 1,3-alternate conformation $\mathbf{3}-\mathbf{5}$ as coordinating organic tectons with $\mathrm{HgCl}_{2}$, a V-shape two-connecting metal-
Table 3. Crystal data for $\left\{\mathrm{Hg}_{2} \mathrm{Cl}_{4}\left(\mathrm{C}_{64} \mathrm{H}_{68} \mathrm{~N}_{4} \mathrm{O}_{4} \mathrm{~S}_{4}\right) \cdot 4 \mathrm{CHCl}_{3}\right\} \cdot \mathbf{5}-\mathrm{HgCl}_{2}$.

\begin{tabular}{ll}
\hline Empirical formula & $\left\{\mathrm{Hg}_{2} \mathrm{Cl}_{4}\left(\mathrm{C}_{64} \mathrm{H}_{68} \mathrm{~N}_{4} \mathrm{O}_{4} \mathrm{~S}_{4}\right) \cdot 4 \mathrm{CHCl}_{3}\right\}$ \\
Formula weight & 2105.92 \\
Temperature & $173(2) \mathrm{K}$ \\
Wavelength & $0.71073 \AA$ \\
Crystal system & Monoclinic \\
Space group & $P 2(1) / n$ \\
Unit cell dimensions & $\mathrm{a}=14.6095(5) \AA \alpha=90^{\circ}$. \\
& $\mathrm{b}=21.1405(7) \AA \beta=95.3600(10)^{\circ}$. \\
& $\mathrm{c}=26.3307(9) \AA \gamma=90^{\circ}$. \\
Volume & $8096.7(5) \AA^{3}$ \\
Z & 4 \\
Density (calculated) & $1.728 \mathrm{Mg} / \mathrm{m}^{3}$ \\
Absorption coefficient & $4.467 \mathrm{~mm})^{-1}$ \\
F(000) & 4144 \\
Crystal size & $0.09 \times 0.06 \times 0.06 \mathrm{~mm}{ }^{3}$ \\
Theta range for data collection & 1.83 to $30.08^{\circ}$. \\
Index ranges & $-20<=\mathrm{h}<=20,-29<=\mathrm{k}<=21$, \\
& $-37<=1<=35$ \\
Reflections collected & 66564 \\
Independent reflections & $23486[\mathrm{R}($ int $)=0.0776]$ \\
Completeness to theta $=30.08^{\circ}$ & $98.7 \%$ \\
Absorption correction & $\mathrm{Semi}-\mathrm{empirical} \mathrm{from} \mathrm{equivalents}$ \\
Max. and min. transmission & 0.7754 and 0.6893 \\
Refinement method & $\mathrm{Full}-\mathrm{matrix}$ least-squares on $\mathrm{F}^{2}$ \\
Data / restraints / parameters & $23486 / 0 / 895$ \\
Goodness-of-fit on F ${ }^{2}$ & 1.088 \\
Final R indices [I 2 sigma(I)] & $\mathrm{R} 1=0.0530, \mathrm{wR} 2=0.0906$ \\
R indices (all data) & $\mathrm{R} 1=0.1098, \mathrm{wR} 2=0.1061$ \\
Largest diff. peak and hole & 1.808 and $-1.511 \mathrm{e} \cdot \AA^{-3}$ \\
\hline &
\end{tabular}

latecton, were explored. Whereas no crystalline material could be obtained using the tecton $\mathbf{3}$, the other two tectons $\mathbf{4}$ and $\mathbf{5}$ lead to the formation of neutral mercury coordination networks in the solid state. Tectons 3 (ortho), 4 (meta) and $\mathbf{5}$ ( para) are positional isomers and differ by the position of the $\mathrm{N}$ atom on the pyridyl coordinating moiety. The dimensional- 
ity of the extended architectures appears to be dependent on the localization of the $\mathrm{N}$ atom. Indeed, whereas tectons $\mathbf{4}$ leads to the formation of a neutral 3D diamond-like architecture, tectons $\mathbf{5}$ forms 1D tubular coordination network. Although for all three tectons 3-5, one may impose the overall 1,3-alternate conformation, these species are not rigid and thus may adopt different shapes. Furthermore, owing to the presence of $-\mathrm{OCH}_{2}$ spacer used to connect the pyridyl units to the thiacalix backbone, tectons 3-5 may behave as different rotamers leading to a variety of orientation of the pyridyl coordinating sites, in particular in the case of tectons $\mathbf{3}$ ( $\mathrm{N}$ atom at the ortho position) and 4 ( $\mathrm{N}$ atom at the meta position). Consequently, for such flexible tectons, it is virtually impossible to predict the formation, the dimensionality as well as the geometry of coordination networks. For that reason, it is compulsory to experimentally investigate the formation of networks by exploring different metal centers and complexes as well as crystallization conditions.

Based on tectons 3-5, the generation of other types of coordination networks using other metal cations or metallatectons is currently under investigation.

Acknowledgments. This work has been supported by Russian Scientific Foundation (grant $\mathrm{N}^{\circ}$ 15-13-30006). We thank the University of Strasbourg, the Institut Universitaire de France (IUF) and icFRC for X-ray experiments and microanalysis.

\section{References}

1. (a) Mann S. Nature 1993, 365, 499; (b) Hosseini M.W. Acc. Chem. Res. 2005, 38, 313.

2. Lehn J.-M. Supramolecular Chemistry: Concepts and Perspectives. VCH, Weinheim, 1995. $271 \mathrm{p}$.

3. Simard M., Su D., Wuest J.D. J. Am. Chem. Soc. 1991, 113, 4696.

4. (a) Abrahams B.F., Hoskins B.F., Robson R. J. Am. Chem. Soc. 1991, 113, 3606; (b) Batten S.R., Robson R. Angew. Chem. Int. Ed. 1998, 37, 1460; (c) Blake A.J., Champness N.R., Hubberstey P., Li W.-S., Withersby M.A., Schröder M. Coord. Chem. Rev. 1999, 193, 117; (d) Moulton B., Zaworotko M.J. Chem. Rev. 2001, 101, 1629; (e) Janiak C. Dalton Trans. 2003, 2781; (f) Carlucci L., Ciani G., Proserpio D.M. Coord. Chem. Rev. 2003, 246, 247; (g) Kitagawa S., Kitaura R., Noro S. Angew. Chem. Int. Ed. 2004, 43, 2334; (h) Férey G., Mellot-Draznieks C., Serre C., Millange F. Acc. Chem. Res. 2005, 38, 218; (i) Bradshaw D., Claridge J.B., Cussen E.J., Prior T.J., Rosseinsky M.J. Acc. Chem. Res. 2005, 38, 273; (j) Kitagawa S., Uemura K.. Chem. Soc. Rev. 2005, 34, 109; (k) Maspoch D., Ruiz-Molina D., Veciana J. Chem. Soc. Rev. 2007, 36, 770; (1) Long J.R., Yaghi O.M. Chem. Soc. Rev. 2009, 38, 1213; (m) Janiak C., Vieth J.L. New J. Chem. 2010, 34, 2366; (n) Chem. Soc. Rev. 2009, 38, themed issue on metal-organic frameworks; (o) Leong W.L., Vittal J.J. Chem. Rev. 2011, 111, 688; (p) Chem. Rev. 2012, 112, metal-organic frameworks special issue.

5. (a) Gutsche C.D. Calixarenes Revisited. Cambridge: The Royal Society of Chemistry, 1998; (b) In: Calixarenes 2001 (Asfari Z., Böhmer V., Harrowfield J., Vicens J., Eds.) Dordrecht: Springer Netherlands, 2001. $676 \mathrm{p}$.

6. Mislin G., Graf E., Hosseini M.W., Cian A.De, Kyritsakas N., Fischer J. Chem. Commun. 1998, 2545.
7. Liu Y-J., Huang J-S., Chui S.S-Y., Li C-H., Zuo J-L., Zhu N., Che C-M. Inorg. Chem. 2008, 47, 11514.

8. Park K-M., Lee E., Park C.S., Lee S.S. Inorg. Chem. 2011, 50, 12085-12090.

9. Dalgarno S.J., Claudio-Bosque K.M., Warren J.E., Glass T.E., Atwood J.L. Chem. Commun. 2008, 1410.

10. Lee J.Y., Lee S.Y., Seo J., Park C.S., Go J.N., Sim W., Lee S.S. Inorg. Chem. 2007, 46, 6221.

11. Lee J.Y., Lee S.Y., Sim W., Park K-M., Kim J., Lee S.S. J. Am. Chem. Soc. 2008, 130, 6902.

12. Lee J.Y., Kim H.J., Jung J.H., Sim W., Lee S.S. J. Am. Chem. Soc. 2008, 130, 13838.

13. Kim J-Y., Park I-H., Lee J.Y., Lee J-H., Park K-M., Lee S.S. Inorg. Chem. 2013, 52, 10176.

14. Lee J.Y., Lee S.Y., Seo J., Park S., Kwon J., Sim W., Lee S.S. Inorg. Chem. 2009, 48, 8934.

15. (a) Kumagai H., Hasegawa M., Miyanari S., Sugawa Y., Sato Y., Hori T., Ueda S., Kamiyama H., Miyano S. Tetrahedron Lett. 1997, 38, 3971; (b) Akdas H., Bringel L., Graf E., Hosseini M.W., Mislin G., Pansanel J., Cian A.De, Fischer J. Tetrahedron Lett. 1998, 39, 2311.

16. Rao P., Hosseini M.W., Cian A.De, Fischer J. Chem. Commun. 1999, 2169.

17. Kozlova M.N., Ferlay S., Solovieva S.E., Antipin I.S., Konovalov A.I., Kyritsakas N., Hosseini M.W. Dalton Trans. 2007, 5126.

18. Kozlova M.N., Ferlay S., Solovieva S.E., Antipin I.S., Konovalov A.I., Kyritsakas N., Hosseini M.W. Chem. Commun. 2009, 2514.

19. Ovsyannikov A., Ferlay S., Solovieva S.E., Antipin I.S., Konovalov A.I., Kyritsakas N., Hosseini M.W. Izv. Akad. Nauk, Ser. Khim. 2015, N. 8, 1955-1962 (in Russ.).

20. Akdas H., Graf E., Hosseini M.W., Cian A.De, Harrowfield J.McB Chem. Commun. 2000, 2219.

21. Zhang Z., Drapailo A., Matvieiev Y., Wojtas L., Zaworotko M.J. Chem. Commun. 2013, 8353.

22. Kim K., Park S., Park K-M., Lee S.S. Cryst. Growth Des. 2011, 11, 4059.

23. Ovsyannikov A., Lang M.N., Ferlay S., Solovieva S.E., Antipin I.S., Konovalov A.I., Kyritsakas N., Hosseini M.W. Dalton Trans. 2013, 116.

24. Ovsyannikov A., Ferlay S., Solovieva S.E., Antipin I.S., Konovalov A.I., Kyritsakas N., Hosseini M.W. CrystEngComm 2014, 3765.

25. Ovsyannikov A., Ferlay S., Solovieva S.E., Antipin I.S., Konovalov A.I., Kyritsakas N., Hosseini M.W. Dalton Trans. 2013, 9946.

26. Ovsyannikov A., Ferlay S., Solovieva S.E., Antipin I.S., Konovalov A.I., Kyritsakas N., Hosseini M.W. Inorg. Chem. 2013, 52, 6776.

27. Ovsyannikov A., Ferlay S., Solovieva S.E., Antipin I.S., Konovalov A.I., Kyritsakas N., Hosseini M.W. Dalton Trans. 2014, 43, 158

28. Ovsyannikov A., Ferlay S., Solovieva S.E., Antipin I.S., Konovalov A.I., Kyritsakas N., Hosseini M.W. Macroheterocycles 2015, 8, 113.

29. Sheldrick G.M. Program for Crystal Structure Solution. Göttingen: University of Göttingen, 1997.

30. (a) Klein C., Graf E., Hosseini M.W., Cian A.De, Fischer J. Chem. Commun. 2000, 239; (b) Laugel G., Graf E., Hosseini M.W., Planeix J.-M., Kyritsakas N. New J. Chem. 2006, 30, 1340; (c) Ehrardt J., Planeix J-M., Kyritsakas-Gruber N., Hosseini M.W. Dalton Trans. 2009, 6309.

31. Mislin G., Graf E., Hosseini M.W., Cian A.De, Kyritsakas N., Fischer J. Chem. Commun. 1998, 2545.

Received 16.11.2015

Accepted 22.12.2015 